\title{
Rare case of adult colocolic intussusception
}

\author{
Talia Shepherd, ${ }^{1}$ Maryam Wazir, ${ }^{2}$ Jacinta Cover ${ }^{2}$
}

${ }^{1}$ General Surgery, Royal Perth Hospital, Perth, Western Australia, Australia ${ }^{2}$ General Surgery, South West Health Campus, Bunbury, Western Australia, Australia

Correspondence to Dr Talia Shepherd; talia.shepherd@health.wa. gov.au

Accepted 4 February 2020

\section{DESCRIPTION}

A 69-year-old man presented with a 2-week history of constipation and severe intermittent periumbilical pain. He also described loss of appetite and $6 \mathrm{~kg}$ loss of weight over the 2-week period. He presented twice to his general practitioner over these 2 weeks, who initially prescribed laxatives for constipation then referred him to the emergency department for ongoing pain. A colonoscopy had been done 9 years earlier for constipation and the patient reported it as unremarkable. He had a family history significant for bowel cancer in a first-degree relative and was a smoker. He was haemodynamically stable with a tender mass in the right upper quadrant on examination.

The patient subsequently had an abdominal CT scan, which revealed a large bowel intussusception of the hepatic flexure into the transverse colon, with a low-density heterogenous soft-tissue mass as the lead point (figure 1A,B) and no features of large bowel obstruction. His blood results showed a raised $\mathrm{C}$ reactive protein (CRP) of 120 but were otherwise unremarkable.

$\mathrm{He}$ underwent an emergency laparoscopicassisted right hemicolectomy, revealing a $6.0 \times 3.5 \mathrm{~cm}$ polypoid submucosal lesion with surrounding tattoo ink in the large bowel lumen with necrotic changes at the tip and otherwise macroscopically normal large bowel mucosa (figure 2). Histopathology confirmed a lipoma with fat necrosis and ischaemic changes but no suspicious features for malignancy. We later correlated this result with his original colonoscopy, which reported a large submucosal mass that was tattooed at the time and biopsies confirming a lipoma. He had an uncomplicated postoperative recovery.

Intussusception is the the most common cause of acute small bowel obstruction in children aged $<3$ years but comprises only $1 \%$ of adult bowel obstruction presentations. ${ }^{1}$ Additionally, in the adult population, a pathological lead point is often identifiable, whereas a minority of paediatric

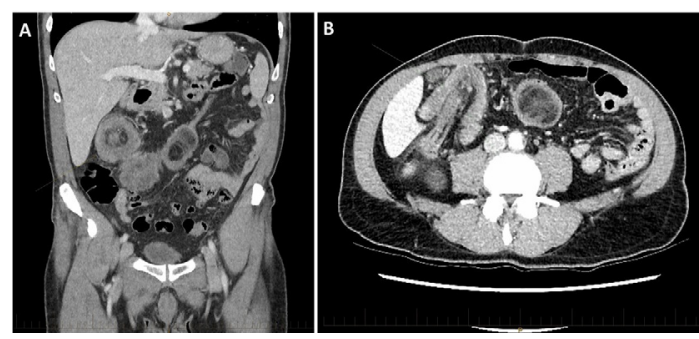

Figure $1 \mathrm{CT}$ of the abdomen showing classical imaging features (A) coronal plane with target sign and (B) axial plane with sausage-shaped telescoping of hepatic flexure into the transverse colon.

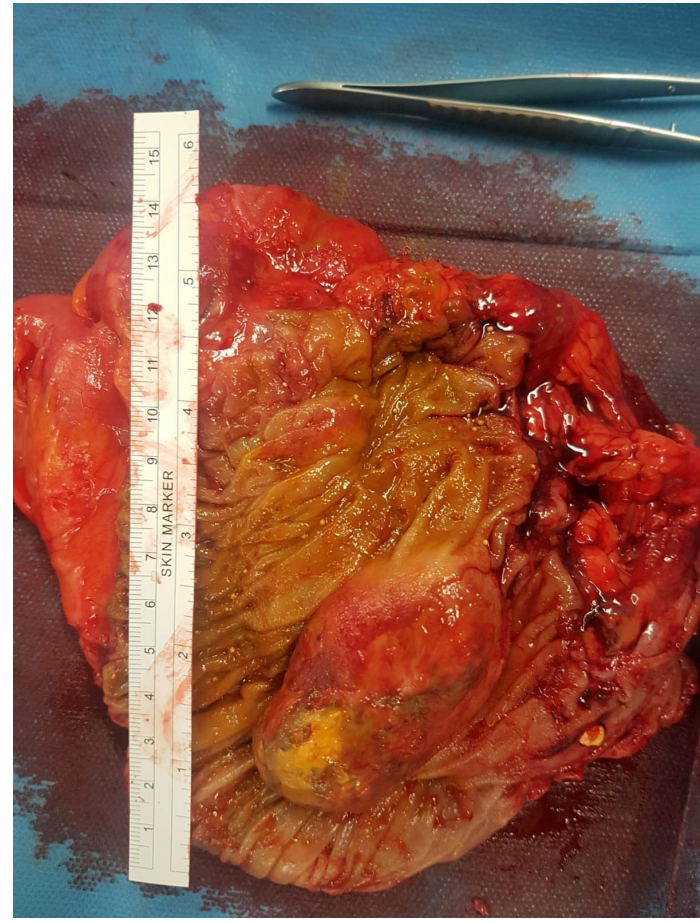

Figure 2 Macroscopic photograph of the specimen showing $6.0 \times 3.5 \mathrm{~cm}$ submucosal lipoma with ischaemic necrosis overlying the tip.

intussusceptions present with a lead point. Of the $1 \%$ adult intussusception, malignancy forms the majority of lead point aetiology (65\%-70\%). ${ }^{1}$ The lead point is pulled forward by normal peristalsis, telescoping or prolapsing the affected segment of bowel (intussusceptum) into another segment of bowel (intussuscipiens). A lipoma is a rare cause of adult intussusception but has been documented in cases worldwide. ${ }^{2}$ This report describes a case of a late presentation of an adult intussusception due to a lipoma with classical imaging findings and intraoperative photographs of the lesion. The role of elective bowel resection in patients with large submucosal lipomas should be considered to prevent future complications.

\section{Learning points}

Large bowel intussusception is rare in adults and is usually due to a malignant lead point.

- The classic imaging features are the 'target' sign and a sausage-shaped mass.

- Consider the role of elective bowel resection in patients with large submucosal lipomas to prevent future complications. 
Contributors TS conceived the project, executed the case write-up and produced the images. MW performed the literature review and contributed to the case write-up. JC edited the final document for submission.

Funding The authors have not declared a specific grant for this research from any funding agency in the public, commercial or not-for-profit sectors.

Competing interests None declared.

Patient consent for publication Obtained.
Provenance and peer review Not commissioned; externally peer reviewed.

\section{REFERENCES}

1 Marinis A, Yiallourou A, Samanides L, et al. Intussusception of the bowel in adults: a review. WJG 2009;15:407.

2 Wang N, Cui X-Y, Liu Y, et al. Adult intussusception: a retrospective review of 41 cases. World I Gastroenterol 2009;15:3303.

Copyright 2020 BMJ Publishing Group. All rights reserved. For permission to reuse any of this content visit

https://www.bmj.com/company/products-services/rights-and-licensing/permissions/

BMJ Case Report Fellows may re-use this article for personal use and teaching without any further permission.

Become a Fellow of BMJ Case Reports today and you can:

- Submit as many cases as you like

Enjoy fast sympathetic peer review and rapid publication of accepted articles

Access all the published articles

Re-use any of the published material for personal use and teaching without further permission

\section{Customer Service}

If you have any further queries about your subscription, please contact our customer services team on +44 (0) 2071111105 or via email at support@bmj.com.

Visit casereports.bmj.com for more articles like this and to become a Fellow 